\title{
MODEL PEMBELAJARAN KOOPERATIF TIPE GROUP INVESTIGATION DALAM PEMBELAJARAN BOLAVOLI
}

\author{
Sumbara Hambali \\ Program Studi PJKR, STKIP Pasundan, \\ Jln. Permana, No. 32 B, Cimahi Utara-Kota Cimahi \\ e-mail: sumbarahambali8@gmail.com
}

\begin{abstract}
Abstrak
Tujuan penelitian adalah untuk mengetahui peningkatan hasil belajar aspek kognitif siswa pada materi bolavoli. Metode yang digunakan adalah metode eksperimen dengan desain randomized control - group pretest - posttestdesign. Sampel penelitiannya adalah siswa kelas X SMAN 1 Ngamprah yang diambil secara cluster random sampling. Instrumen yang digunakan adalah tes soal pengetahuan bola voli. Berdasarkan hasil penelitian didapat bahwa nilai thitungpada model pembelajaran groupinvestigation adalah 3,546 lebih besar dari ttabel yaitu 2,042. Sedangkan pada pembelajaran konvensional mempunyai thitung sebesar 2,318 yang juga lebih besaar dari ttabel yaitu 2,042. Dengan demikian dapat disimpulkan bahwa penerapan model pembelajaran groupinvestigation dan pembelajaran konvensional memiliki pengaruh yang signifikan terhadap hasil belajar aspek kognitif siswa pada materi bola voli. Dan berdasarkan hasil rata-rata yang diperoleh dari masing-masing kelompok, dapat disimpulkan bahwa penerapan model pembelajaran kooperatif tipe group investigation lebih berpengaruh terhadap hasil belajar aspek kognitif siswa pada materi bola voli.
\end{abstract}

Kata kunci : Model Pembelajaran GroupInvestigation, Aspek Kognitif, Bola Voli.

\begin{abstract}
The purpose of this study was to determine the improvement of students' cognitive learning outcomes in volleyball material. The research method used is an experimental method with a randomized control - group pretest - posttest design. The research sample was students of class $X$ of SMAN 1 Ngamprah taken by cluster random sampling. The instrument used is a test of volleyball knowledge. Based on the results of the study, it was found that the $t$ count in the group investigation learning model was 3.546 greater than the t table of 2.042. Whereas in conventional learning has a $t$ count of 2.318 which is also greater than the $t$ table of 2.042. Thus it can be concluded that the application of the group investigation learning model and conventional learning has a significant influence on the learning outcomes of cognitive aspects of students on volleyball material. And based on the average results obtained from each group, it can be concluded that the application of cooperative learning model type investigation group has more influence on the learning outcomes of cognitive aspects of students on volleyball material.
\end{abstract}

Keywords: Group Investigation Learning Model, Cognitive Aspect, Volleyball. 


\section{PENDAHULUAN}

Salah satu olahraga pendidikan jasmani yang ada di sekolah adalah pembelajaran bola voli. Dalam pembelajaran pendidikan jasmani permainan bola voli mungkin sudah umum pada dasarnya dan terdiri dari beberapa teknik dasar seperti service, passing, smash, dan block.

Dalam proses pembelajaran seorang guru harus bisa menciptakan suasanan yang menyenangkan dalam memberikan materi. Tetapi masih ada sebagian guru yang belum bisa menyampaikan suatu proses pembelajaran dengan metode pembelajaran yang tepat, apabila menyampaikan suatu proses pembelajaran dengan penyampaian yang kurang efektif akan memberikan kejenuhan kepada siswa.

Fenomena di lapangan, masih ada sebagian guru yang belum bisa menyampaikan suatu proses pembelajaran dengan model pembelajaran yang tepat, sehingga akan memberikan kejenuhan dan ketidak pahaman kepada siswa. Dengan waktu yang sangat terbatas guru dituntut untuk membuat siswa aktif dalam bergerak dan mendapatkan pengetahuan serta perubahan sikap yang lebih baik dari sebelumnya, sehingga penerapan model pembelajaran haruslah dapat mewakili tujuan tersebut. Dan fakta dilapangan guru mengajar tanpa menggunakan model pembelajaran. Sedangkan model pembelajaran itu perlu untuk tercapainya suatu pembelajaran. Terutama dipembelajaran penjas guru hanya mencakup ranah psikomotor tidak mementingkan ranah kognitif siswa.

Salah satu model yang dikembangkan dalam pembelajaran penjasorkes adalah model Cooperative Learning tipe group investigation (IG). Model ini merupakan model pembelajaran berkelompok yang menekankan setiap kelompok mencari informasi mengenai topik yang diberikan dari berbagai sumber seperti buku, Koran, majalah, ataupun internet. Kemudian siswa mempresentasikan hasil temuannya atau hasil investigasinya kepada teman-teman kelompok yang lain.

Berdasarkan uraian tersebut, maka penlitian ini berpusat pada aspek kognitif siswa dengan penggunaan model pembelajaran kooperatif tipe group investigation. Sehingga dapat dirumuskan permasalahannya adalah penerapan 
model pembelajaran kooperatif tipe group investigation dalam pembelajaran bola voli, dengan tujuan untuk mengetahui peningkatan aspek kognitif siswa dalam materi bola voli.

\section{METODE}

Metode yang digunakan dalam penelitian ini adalah eksperimental, dengan desain Randomized Control - Group Pre-Test - Posttest Design yang bentuk bagannya dapat ditujukan sebagai berikut:

$\begin{array}{|lr|}\mathrm{T} 1 \longleftarrow \mathrm{X} & \mathrm{T} 2 \\ \mathrm{~T} 1 \ldots \mathrm{T} 2\end{array}$

\section{Gambar 1 Randomized Control - Group PreTest - PostTest Design}

Keterangan:

$T_{1}=$ Tes awal (pra test) dengan angket soal bola voli.

$X_{1}=$ Perlakuan (Model Pembelajaran Kooperatif tipe Group Investigation .

$T_{2}=$ Tes akhir (post test) dengan angket soal bola voli.

Penelitian dilakukan 1 kali pertemuan disetiap minggu nya selama 5 minggu, berlandaskan pada penelitian yang telah dilakukan oleh Endang pada siswa SMPN 3 Tanggerang Selatan. Penelitian dilakukan dengan frekuensi 1 kali per minggu. Durasi setiap pertemuan 3 x 45 menit berlandaskan pada kurikulum yang digunakan di sekolah SMAN 1 Ngamprah.

Perlakuan Model Pembelajaran kooperatif tipe Group Investigation diberikan kepada kelompok A. Pretest dilakukan sebelum perlakuan diberikan yaitu pembelajaran mata pelajaran bola voli dengan menggunakan model pembelajaran Kooperatif tipe Group Investigation. Perlakuan dilakukan pada sampel sebagai kelompok eksperimen dengan menggunakan model pembelajaran Kooperatif tipe Group Investigation dalam pembelajaran mata pelajaran bola voli. Pada kelompok B Pretestdilakukan sebelum perlakuan diberikan yaitu pembelajaran konvensionaldan posttest tanpa diberikan perlakuan. 
Populasi dalam penelitian ini seluruh siswa kelas X di SMAN 1 Ngamprah yang berjumlah 216. Sedangkan sampel dalam penelitian ini adalah sebanyak 60 orang dengan cara teknik pengambilan sampel adalah teknik random sampling.Intrumen yang digunakan dalam penelitian ini yaitu tes pengetahuan berupa objektif tipe pilihan ganda, terdiri dari 40 pertanyaan dengan 4 pilihan jawaban dalam setiap soalnya. Instrumen tersebut diuji coba dengan teknik analisiskorelasiproduct moment dan didapat jumlah soal yang valid sebanyak 30 soal. Teknik analisis data yang digunakan adalah dengan analisis uji t dengan kesamaan dua rata-rata, dengan terlebih dahulu mencari nilai rata-rata dan simpangan baku, serta uji normalistas dan uji homogenitas.

\section{HASIL DAN PEMBAHASAN}

\section{Deskripsi Data}

Data-data yang diperoleh mengenai seberapa pengaruhkah model pembelajaran kooperatif tipe groupinvestigation dan pembelajaran konvensionalterhadap pengetahuan bola voli dalam pendidikan jasmani, menggunakan tes objektif tipe pilihan ganda sebagai alat untuk melakukan penelitian ini. Hasil perhitungan rata-rata dan simpangan baku dapat dilihat pada table berikut ini:

Tabel 1 Hasil Perhitungan Rata-Rata Dan Simpangan Baku

\begin{tabular}{ccccc}
\hline Kelompok & Kategori & N & Rata-rata & Simpangan Baku \\
& Tes awal & 30 & 16.13 & 5.64 \\
Eksperimen & Tes akhir & 30 & 20.5 & 7.12 \\
& Tes awal & 30 & 16 & 6.38 \\
& Tes akhir & 30 & 19.3 & 8.78 \\
\hline
\end{tabular}

Berdasarkan tabel 1, dikemukakan bahwa pada kelompok A (model pembelajaran group investigation), rata-rata hasil tes awal sebesar 16.13 dan ratarata tes akhir sebesar 20.5. Sedangkan simpangan baku hasil tes awal sebesar 5.64 dan simpangan baku tes akhir sebesar 7.12.Pada kelompok B (pembelajaran konvensional), rata-rata hasil tes awal sebesar 16 dan rata-rata tes akhir sebesar 
19.3. Sedangkan simpangan baku hasil tes awal sebesar 6,38 dan simpangan baku tes akhir sebesar 8.78 .

\section{Uji Persyaratan Analisis}

\section{Uji normalitas}

Pengujian normalitas dilakukan dengan menggunakan pendekatan uji kenormalan Lilliefors.Untuk menerima atau menolak hipotesis nol caranya membandingkan nilai L hitung (Lo) dengan nilai kritis L yang diambil dari table lilliefors.

Tabel 2 Hasil Uji Normalitas

\begin{tabular}{ccccc}
\hline Kelompok & Kategori & Lo Hitung & L Tabel $\boldsymbol{\alpha} \mathbf{0 , 0 5}$ & HASIL \\
& Tes Awal & 0.096 & 0,161 & Normal \\
Kelompok A & Tes Akhir & 0.120 & 0,161 & Normal \\
& Tes Awal & 0.104 & 0,161 & Normal \\
Kelompok B & Tes Akhir & 0.153 & 0,161 & Normal \\
\hline
\end{tabular}

Berdasarkan pada tabel 2 dapat dikemukakan bahwa (1) pada kelompok A (model pembelajaran groupinvestigation) diperoleh Lo hitung tes awal sebesar 0.096 dan diperoleh Lo hitung tes akhir sebesar 0.120. Dari perhitungan diketahui bahwa nilai Lo hitung untuk tes awal dan tes akhir tersebut lebih kecil dari Ltable 0.161. Maka dapat disimpulkan bahwa data tes awal dan tes akhir kelompok A berdistribusi normal. (2) Pada kelompok B (pembelajaran konvensional) diperoleh Lo hitung tes awal sebesar 0.104 dan diperoleh Lo hitung tes akhir sebesar 0.153. Dari perhitungan diketahui bahwa nilai Lo hitung untuk tes awal dan tes akhir tersebut lebih kecil dari L table 0.161. Maka dapat disimpulkan bahwa data tes awal dan tes akhir kelompok A berdistribusi normal.

\section{Uji homogenitas}

Pengujian homogenitas data dari masing-masing variable, hasilnya dapat dilihat dari tabel 3 berikut.

Tabel 3 Hasil Perhitungan Homogenitas

\begin{tabular}{cccc}
\hline Kelompok & F hitung & F tabel & Hasil \\
Pretest Kelompok & 1.305 & 1.860 & Homogen \\
\hline
\end{tabular}


A dan kelompok B

Posttest Kelompok A dan kelompok B

1.519

1.860

Homogen

Nilai $\mathrm{F}$ hitung pretest kelompok $\mathrm{A}$ dan kelompok $\mathrm{B}=1.305$ dan $\mathrm{F}$ hitung posttest kelompok $\mathrm{A}$ dan kelompok $\mathrm{B}=1.519$ lebih kecil daripada $\mathrm{F}$ tebel 1.860 , maka hipotesis dapat diterima. Dengan kata lain bahwa distribusi data tes awal dan tes akhir tersebut mempunyai varian yang homogen.

\section{Uji signifikansi}

Pada perhitungan uji hipotesis digunakan pendekatan uji perbedaan dua rata-rata tujuannya untuk mengetahui seberapa besar pengaruh model pembelajaran groupinvestigation dan pembelajaran konvensional terhadap pengetahuan siswa SMAN 1 Ngamprah.

Tabel 4 Hasil Uji Model Pembelajaran Group Inventigation Terhadap

\section{Pengetahuan Bola Voli}

\begin{tabular}{|c|c|c|}
\hline t-Test: Paired Two Sample For Means & Pre test & Post test \\
\hline Mean & 16.133 & 20.5 \\
\hline Variance & 31.843 & 50.810 \\
\hline Simpangan gabungan $(\mathrm{S})$ & \multicolumn{2}{|c|}{6.743} \\
\hline A & \multicolumn{2}{|c|}{0.05} \\
\hline $\begin{array}{l}\mathrm{N} \\
\mathrm{T}=\frac{x_{1}-x_{2}}{=}=\end{array}$ & \multirow{2}{*}{\multicolumn{2}{|c|}{3.546}} \\
\hline$\sqrt[s]{\frac{1}{n 1}+\frac{1}{n 2}}$ & & \\
\hline $\begin{array}{l}\text { t-hitung } \\
\text { t-tabel }\end{array}$ & \multicolumn{2}{|c|}{2.042} \\
\hline
\end{tabular}

Tabel 5 Hasil Uji Model Pembelajaran Konvensional Terhadap Pengetahuan Bola Voli

\begin{tabular}{lcc}
\hline \multicolumn{1}{c}{ t-Test: Paired Two Sample For Means } & Pre test & Post test \\
Mean & 16 & 19.3 \\
Variance & 40.827 & 77.182 \\
Simpangan gabungan (S) & \multicolumn{2}{c}{7.795} \\
A & 30 & 0.05 \\
N & \multicolumn{2}{c}{30} \\
t-hitung $=$ & \multicolumn{2}{|c}{} \\
T $=\frac{\boldsymbol{x}_{\mathbf{1}}-\boldsymbol{x}_{\mathbf{2}}}{\sqrt[s]{\frac{\mathbf{1}}{\boldsymbol{n} \mathbf{1}}+\frac{\mathbf{1}}{\boldsymbol{n} \mathbf{2}}}=}$ & & \\
t-tabel & & \\
\end{tabular}


Dapat dilihat dari tabel uji perbedaan dua rata-rata model pembelajaran groupinvestigation terhadap pengetahuan bola voli t-hitung bernilai 3.546 dengan tabel untuk uji dua pihak adalah bernilai $3.546>2.042$ t-tabel. Sedangkan uji perbedaan dua rata-rata pembelajaran konvensional terhadap pengetahuan bola voli t-hitung bernilai 2.318 dengan tabel untuk uji dua pihak adalah $2.318>2.042$, maka kedua nilai rata-rata pengetahuan bola voli antara siswa yang diberi perlakuan model pembelajaran groupinvestigation dengan yang tidak diberi perlakuan terdapat perbedaan yang signifikan.

Hasil penelitian ini mendukung hipotesis pertama, kedua dan ketiga bahwa penerapan model pembelajaran groupinvestigation dan pembelajaran konvensional dalam pembelajaran penjas berpengaruh secara signifikan terhadap pengetahuan bola voli siswa di SMAN 1Ngamprah. Meskipun keduanya berpengaruh secara signifikan terhadap pengetahuan bola voli siswa, model pembelajaran groupinvestigation memberikan pengaruh yang lebih signifikan dibandingkan pembelajaran konvensional.

\section{SIMPULAN}

Berdasarkan hasil penelitian yang penulis lakukan serta perhitungan dan analisis data dari hasil pengukuran, maka pada bagian ini penulis dapat mengemukakan kesimpulan sebagai berikut:

1. Model pembelajaran kooperatif tipe group investigation (GI) memberikan pengaruh yang signifikan terhadap pengetahuan permainan bola voli pada siswa di SMAN 1 Ngamprah.

2. Model pembelajaran konvensional memberikan pengaruh yang signifikan terhadap pengetahuan permainan bola voli pada siswa di SMAN 1 Ngamprah.

3. Terdapat perbedaan pengaruh antara model pembelajaran kooperatif tipe group investigation (GI) dan model pembelajaran konvensional terhadap pengetahuan permainan bola voli pada siswa di SMAN 1 Ngamprah.Model pembelajaran groupinvestigation memberikan pengaruh yang lebih signifikan 
dibandingkan pembelajaran konvensional terhadap pengetahuan permainan bola voli pada siswa di SMAN 1 Ngamprah.

\section{DAFTAR PUSTAKA}

Endang. 2014. Pengaruh Strategi Pembelajaran Kooperatif Tipe Group Investigation Terhadap Hasis Belajar Siswa Pada Mata Pelajaran PAI. Online: repository.uinjkt.ac.idENDANG-FITK, diakses 2014.

PBVSI. 2013.Peraturan Permainan Bola Voli. Jakarta: PP. PBVSI.

Kurniawan, F. 2011.Buku Pintar Olahraga Mens Sana In Corpore Sano. Jakarta: Laskar Aksara.

Kumar, A. 2010.DPH Sport Series Volleyball (New Delhi: Discovery Publishing House.

Viera, L B, dan Fergusson, J B. 2010.Bola Voli Tingkat Pemula terjemahan Monti. Jakarta: PT. Raja Grafindo Persada.

Trianto. 2010. Macam-Macam Model Pembelajaran dan Aplikasinya. Bandung: PT. Grasindo.

Slavin, R.E. 2009. Cooperative Learning. Boston: Allyn Bacon.

Sugiyono. 2013. Metode Penelitian Pendidikan. Bandung: Alfabeta. 